\title{
1. The emerging roles of cities in international law - introductory remarks on practice, scholarship and the Handbook
}

\author{
Helmut Philipp Aust and Janne E. Nijman
}

\section{A NEW RESEARCH FIELD IN AND FOR INTERNATIONAL LAW}

Over the past three decades, a rich and diverse research field has developed, dealing with the increasingly global activities as well as character and role of cities in the age of globalisation. No longer just sites of 'the local', cities are spaces where global influences play out just as well, as they have become actors that meaningfully contribute to shaping what we imagine 'the global' to be. Contributions to this dynamic research field stem from various disciplines: first sociologists and urban geographers took note of new dynamics in the relationships between the global and the local, with a particular focus on how the shift from the international to the global economy during the 1970 s and 1980 s affected and reconstituted cities. ${ }^{1}$ Other academic fields followed suit. Historians dealt with the role that cities played in the multiple networks and interconnections in which especially the sub-field of global history takes a keen interest. ${ }^{2}$ In the field of political science, scholars of international relations (IR) started to analyse how the emergence of city networks created new forms of diplomacy and transformed the world-system. ${ }^{3}$ The city in all its dimensions is a classical theme in art history. Today, Franz Ackermann brings urbanism and globalism together in his work on the unsafe grounds on which the lived experiences of contemporary cities rest. ${ }^{4}$

Law as an academic field has been a latecomer to this development. There are several reasons for this slow embrace. Local government lawyers who primarily deal with cities and the legal forms in which city governments act are traditionally not too concerned with international discourses and debates. ${ }^{5}$ International lawyers, on the other hand, have tended to neglect this development for quite some time as well, possibly due to the traditional state-centric outlook

\footnotetext{
1 Saskia Sassen, The Global City - New York, London, Tokyo (2nd edn, Princeton University Press 2001).

2 Renaud Payre and Pierre-Yves Saunier, 'A City in the World of Cities. Lyon, France; Municipal Associations as Political Resources in the Twentieth Century' in Pierre-Yves Saunier and Shane Ewen (eds), Another Global City. Historical Explorations into the Transnational Municipal Movement (Palgrave Macmillan 2008) 69.

${ }_{3}$ Simon Curtis, 'Global Cities and the Transformation of the International System' (2011) 37 Review of International Studies 1923; Michele Acuto, Global Cities, Governance and Diplomacy The Urban Link (Routledge 2013); Sofie Bouteligier, Cities, Networks, and Global Environmental Governance. Spaces of Innovation, Places of Leadership (Routledge 2013).

4 See the cover of this book.

5 For a notable exception see Jean-Bernard Auby, Droit de la ville - Du fonctionnement juridique des villes au droit à la ville (LexisNexis 2013).
} 


\section{Research handbook on international law and cities}

that the mainstream of the discipline has cultivated with respect to sources and subjectivity, two key categories that serve the purpose of defining what is part of international law and what is irrelevant - as mere politics, governance or morals. From the perspective of a discipline that focuses on the state and aims to transcend national boundaries and study 'the international', it was maybe also counter-intuitive to concern itself with local phenomena, carrying with them a whiff of pettiness and irrelevance. This state of affairs began to change around 2006 when a first wave of contributions of the global dimension of cities and their engagement with international law began to appear. ${ }^{6}$ Since then, the relationship between cities and international law has been scrutinised by an increasing number of contributions. In 2017, the International Law Association decided to set up a Study Group on 'The role of cities in international law', an endeavour that is now well underway and that has, among other activities, started an online repository of 'city reports', which aspires to set out how cities around the globe engage with international law. ${ }^{7}$ The publication of this Research Handbook is further testimony to this development. It marks the coming into existence of an actual research field that takes stock of the varying roles that cities play in and for international law.

In the following introductory remarks, we will first briefly recap the emergence of cities as global actors (section II) before describing how international law scholarship has moved from neglect to a careful embrace of the phenomenon of cities as global actors in the last ten years (section III). Building on this state of the art, we develop a number of research perspectives that are structuring the emerging field at the moment and that also help to organise this Handbook (section IV). Here, we set out the common assumptions underlying this collective book project. Whereas we have decided to take a firm commitment to plurality of perspectives and approaches within these pages, some cross-cutting considerations are nevertheless present and the contributors to this volume are animated by a shared curiosity about a number of common themes.

\section{THE EMERGENCE OF CITIES AS GLOBAL ACTORS}

In the beginning there was The Global City - a thought-provoking book by sociologist Saskia Sassen published in its first edition in $1991 .{ }^{8}$ Dealing with London, New York and Tokyo as three case studies, Sassen highlighted how specific cities had come to occupy central positions (or a function as 'nodes') in the global economy, particularly with respect to the financial sector. Sassen also discussed what this development did to the inhabitants of these cities, or at least to some of them, one should say, and how the development of these metropolises into global cities was in turn also driven by these individuals and their corporate headquarters. In particular, the employees of the global financial industry became detached to a certain extent from their local conditions, the narrow corset of their respective nationalities and came

6 Gerald Frug and David J. Barron, 'International Local Government Law' (2006) 38 The Urban Lawyer 1; Yishai Blank, 'The City and the World' (2006) 44 Columbia Journal of Transnational Law 868; Yishai Blank, 'Localism in the New Global Legal Order' (2006) 47 Harvard International Law Journal 263.

7 The mandate of the ILA Study Group is reproduced in the Annex to this volume; the city reports can be accessed at <https://www.asser.nl/global-city/ila-city-reports/> accessed 19 April 2021.

8 Sassen (n 1). 
to feel as belonging more to a class of global citizens. The book was published at the exact right moment. There was earlier work by researchers coming from the so-called 'world cities literature' like John Friedmann that had looked at similar phenomena. ${ }^{9}$ But Sassen deliberately chose a different term to conceptualise something very specific and timely, something distinct from the urban in earlier centuries: the global city was part of 'a new type of conceptual architecture' aimed at capturing how 'globalisation of economic activity entail[ed] a new type of organisational structure'. ${ }^{10}$ It spoke to the global urban imaginary with great success; 'the global city' came to be associated with the work of Saskia Sassen like none other. Her book was published right after the end of the Cold War; a time that prompted some public intellectuals to ponder the idea of an 'End of History'. ${ }^{11}$ With the (perceived) end of the bipolar confrontation of the Cold War, so too the era of the nation state seemed to come to an end. ${ }^{12}$ Heavily influenced by a mounting neoliberal Zeitgeist, there was much disdain for the state as concept, idea and political category. ${ }^{13}$ Sassen's work opened up the eyes of many to new connections between the global and the local. While her work at first did not specifically look at cities as global actors and, for instance, how they engage with each other and with international organisations (IOs), it was in tune with a development that saw the state partly receding from the central role it had occupied in the decades running up to the Cold War. ${ }^{14}$

At first, this development seemed to work to the benefit of the international institutions that had been created after the Second World War but that had not been able to realise their full potential due to, among other reasons, the bipolarity of the Cold War. The United Nations Security Council seemed to blossom, new international institutions in the fields of international economic law and international criminal law sprang up and the inter-state system also seemed to embrace the challenge of sustainable development with the results of the much-acclaimed Earth Summit in Rio de Janeiro in 1992. A framework convention on climate change was adopted ${ }^{15}$ and international law, at least in retrospect, seemed to gain ever more relevance by the day. ${ }^{16}$

But soon cracks in this rosy image began to appear. The conflicts in the former Yugoslavia and Rwanda showed the still existing limits of the Security Council in the face of political blockade. And the climate change regime did not develop as it had been anticipated in the

9 John Friedmann and Goetz Wolff, 'World City Formation. An Agenda for Research and Action' (1982) 6 International Journal of Urban and Regional Research 309.

10 Saskia Sassen, 'The Global City: Introducing a Concept' (2005) 11 (2) Brown Journal of World Affairs 28.

11 Francis Fukuyama, The End of the History and the Last Man (Free Press 1992).

12 Jean-Marie Guehenno, The End of the Nation State (University of Minnesota Press 1995), translation of La Fin de la Démocratie (Flammarion 1993); Kenichi Ohmae, The Rise of the Regional State: The End of the Nation State (Free Press 1994).

13 Jennifer Mathews, 'Power Shift - The Age of Nonstate Actors' (1997) 76 (1) Foreign Affairs 50.

14 Christoph Schreuer, 'The Waning of the Sovereign State - Towards a New Paradigm for International Law?' (1993) 4 European Journal of International Law 447; also Anne-Marie Slaughter, 'The Real New World Order' (1997) 76(5) Foreign Affairs 183, at 184 discusses how the State is 'disaggregating into its separate, functionally distinct parts'.

15 United Nations Framework Convention on Climate Change of 9 May 1992, entered into force 21 March 1994, 1771 UNTS 1007 (UNFCCC).

16 Heike Krieger and Georg Nolte, 'The International Rule of Law - Rise or Decline? Approaching Current Foundational Challenges' in Heike Krieger, Georg Nolte and Andreas Zimmermann (eds), The International Rule of Law - Rise or Decline? (Oxford University Press 2018) 3, 5. 
early 1990s. While the Kyoto Protocol was successfully negotiated as the first agreement with binding targets for emission reductions at least for some states, missing ratifications from important states like the United States and the long-elusive search for a follow-up agreement increasingly challenged the optimism that had prevailed in the early $1990 \mathrm{~s}^{17}$

Especially in the climate change context, there was an intensifying debate about a 'governance gap' left by the inaction and complacency of states in response to global (development) challenges. ${ }^{18}$ Other actors tried to fill this governance gap, including cities and the networks that they created. Some of these networks were already created as a consequence of the 1992 Rio Declaration and its call to formulate 'Local Agenda 21' documents. ICLEI, an association of today more than 1500 members, is a direct offspring of this development. ${ }^{19}$ While, during the Cold War, 'sister-city' programmes and other bilateral city relations were generally steeped in overcoming Cold War tensions by citizen diplomacy and personal relations at the local level, ${ }^{20}$ after the Cold War inter-city relations moved away from these ideologically loaded initiatives and moved to the level of local governments driven by shared objectives. In the first years of the new millennium, a new type of city network has sprung up, of which ' $\mathrm{C} 40$ - Climate Leadership Group' has become the most conspicuous example. ${ }^{21}$ Founded in 2005 upon the initiative of the then London Mayor Ken Livingstone, the idea was to replicate the club model of G7/8 and G20 respectively and bring it to the city level. C40 rapidly succeeded in putting itself firmly on the map of global climate governance. Especially under the stewardship of New York City Mayor Michael Bloomberg, C40 became known as the blueprint for a successful city network: present at international summits and conferences, heavily imbued in the language of global governance and successful in the creation of networks and alliances with other actors, in the case of $\mathrm{C} 40$ ranging from the World Bank to multiple big corporate actors.

City activities in the field of climate change governance have received particular attention in the last couple of years. ${ }^{22}$ Yet, they are only the proverbial tip of the iceberg by now. City networks, that is transnational networks of local governments, have sprung up in various other fields, pertaining to subject matters as diverse as development, human rights, migration, health governance, security governance and transportation. Not all of these transnational city networks (TCNs) are as corporate-driven as $\mathrm{C} 40$ is, which shows that there is considerable variation among the examples of this new form of international cooperation between cities. ${ }^{23}$

The existence of such TCNs is just one emanation of the global engagement of cities. Other forms of interaction include cooperation between international organisations and city govern-

\footnotetext{
17 Georg Nolte, Treaties and their Practice-Symptoms of their Rise or Decline (Brill Nijhoff 2018) $160-161$.

18 Michele Acuto and Steve Rayner, 'City Networks: Breaking Gridlocks or Forging (New) Lock-ins?' (2016) 92 International Affairs 1147, 1149.

19 See $<$ https://www.iclei.org/> accessed 6 November 2020.

20 Patrick Le Galès, European Cities - Social Conflicts and Governance (Oxford University Press 2002) 105-106; Shane Ewen, 'Lost in Translation? Mapping, Molding, and Managing the Transnational Municipal Movement' in Pierre-Yves Saunier and Shane Ewen (eds), Another Global City - Historical Explorations into the Transmunicipal Movement, 1850-2000 (Palgrave Macmillan 2008) 173, 175-176.

${ }_{21} \quad$ See $<$ https://www.c40.org/> accessed 6 November 2020.

22 See the contributions in (n 3 ).

23 For a comparison of different networks in the climate change context see David Gordon and Michele Acuto, 'If Cities are the Solution, What are the Problems? The Promise and Perils of Urban Climate Leadership' in Craig Johnson, Noah Toly and Heike Schroeder (eds), The Urban Climate Challenge - Rethinking the Role of Cities in the Global Climate Regime (Routledge 2015) 63.
} 
ments. Many IOs seek direct contact with the level of local government these days. The practice of the World Bank, which has contracted directly with city governments since the 1970s, is only the most notable example. ${ }^{24}$ Another prominent city network, 'United Cities and Local Governments', ${ }^{25}$ has for example observer status at the United Nations General Assembly and the International Organization for Migration (IOM). Most recently, the United Nations has increasingly been targeting its operational work on the promotion of the rule of law directly at sub-state actors, thereby potentially bypassing the level of the nation state and its government through which cooperation with actors on the ground has traditionally been channelled. ${ }^{26}$

At the same time, cities are also increasingly exposed to normative expectations coming from the international level. This is evident already for the reason that cities are state organs and are thus bound to comply with the international legal obligations of their respective state, all the differences in organising the relationship between national and international law notwithstanding. Cities are bound, for example, to the norms of human rights law just as they are to the rules of international investment law and have accordingly, through their practice, triggered court cases and arbitrations..$^{27}$ Beyond that level of formal obligations, there is another, increasingly dense layer of documents like the 2015 'Sustainable Development Goals' ${ }^{28}$ (SDGs) and the 'New Urban Agenda' adopted at the Habitat III Conference in Quito $2016 .{ }^{29}$ SDG 11 sets out that cities are to become 'inclusive, safe, resilient and sustainable' by 2030. Even if the meaning of these terms may be vague, they are a clear indication that urban governance is today no longer just a matter for domestic law..$^{30}$ Instead, there is an increasingly global discourse about what good urban governance means. Moreover, this is not an unidirectional development.

To the same extent that cities have become exposed to global norms, they have also begun to make use of international norms, sometimes as levers for fights with their respective central government. Some US cities now routinely claim to step in where the United States does not ratify international agreements. ${ }^{31}$ Local implementation of agreements like the Kyoto Protocol or human rights treaties is one consequence of this move. ${ }^{32}$ Sanctuary or refuge cities around

24 Michael Riegner, 'International Institutions and the City: Towards a Comparative Law of Glocal Governance' in Helmut Philipp Aust and Anél du Plessis (eds), The Globalisation of Urban Governance - Legal Perspectives on Sustainable Development Goal 11 (Routledge 2019) 38.

25 See < https://www.uclg.org/> accessed 10 November 2020.

26 With a specific focus on the work of UN Women see Hannah Birkenkoetter, 'Ensuring Access to Public Space as a Dimension of "Safe Cities": The Role of UN Entities in Shaping the Global Urban Governance Agenda' in Helmut Philipp Aust and Anél du Plessis (eds), The Globalisation of Urban Governance - Legal Perspectives on Sustainable Development Goal 11 (Routledge 2019) 127.

27 For just three examples, see: Case Concerning Elettronica Sicula S.p.a. (ELSI) (United States of America v. Italy), ICJ Rep 1989, 15, paras 30, 70; Öneryildiz v. Turkey, App no. 48949/99 (ECtHR, 30 November 2004); Metalclad v. United Mexican States, ICSID Case No. ARB(AF)/97/1, para. 73.

28 UNGA Res 70/1 (21 October 2015) UN Doc. A/RES/70/1.

29 The New Urban Agenda, adopted at the Habitat III Conference in Quito, 2016, endorsed by the UNGA in Res 71/256 (25 January 2017) UN Doc. A/RES/71/256.

30 Helmut Philipp Aust and Anél du Plessis, 'Good Urban Governance as a Global Aspiration: On the Potential and Limits of Sustainable Development Goal 11' in Duncan French and Louis Kotzé (eds), Sustainable Development Goals: Law, Theory and Implementation (Edward Elgar 2018) 201.

31 See, for instance, Lesley Wexler, 'Take the Long Way Home: Sub-Federal Integration of Unratified and Non-Self-Executing Treaty Law' (2006) 28 Michigan Journal of International Law 1.

32 Judith Resnik, Joshua Civin and Joseph Frueh, 'Ratifying Kyoto at the Local Level: Sovereigntism, Federalism, and Translocal Organizations of Government Actors’ (2008) 50 Arizona Law Review 709. 
the world mobilise human rights law to give a basis for their 'disobedience' of national migration law and policy. ${ }^{33}$ Or consider the case of New York City, which declared itself in 2018 to be the first city to report directly to the United Nations on the local implementation of the SDGs. ${ }^{34}$ Also cities in the 'Global South' become norm entrepreneurs, like in the case of Porto Alegre, which has established itself as reference point for debates on participatory budgeting and has built transnational networks around this idea. ${ }^{35}$ Or take for example Quito where in 2016 its mayor, Mauricio Rodas, hosted UN-Habitat III and emphasised the importance of the New Urban Agenda for the realisation of the SDGs, particularly SDG 11 on Sustainable Cities and Human Settlements. ${ }^{36}$ Here as well as in other cases one needs to be careful with assessments and easy conclusions. At times, city governments and their mayors get carried away when celebrating how they now play a role at the international level. A lot of what is going on may be exercises in public relations. ${ }^{37}$ But that does not mean that they do not matter. And some exercises, forms of cooperation and engagements with international law may be meaningful and should not be discounted out of hand just because there is a suspicion that some of these global activities by cities may be driven by ulterior political motives (which also raises the question to which part of the practice of international law by other actors, notably the state, this would not hold true). When cities engage with international norms proactively and initiate implementation independently, when not bound through their state, this is generally steeped in the 'influential' or 'persuasive' authority of the values these norms capture. ${ }^{38}$ Through the engagement with these norms, cities in turn constitute themselves as actors relevant in international law. ${ }^{39}$

In a nutshell, there is by now a rich yet diverse practice of cities engaging with the international and global levels. The directions of exchange are manifold in this regard. It would be too simplistic to assume that cities are just at the receiving end of globalisation. While they are affected by international norms and by decisions of international institutions, they are also shaping developments on the global level. Some of these developments are driven

33 Blanca Garcés Mascareñas and Kristin Eitel, 'Sanctuary Cities: A Global Perspective', published online in June 2019 on the website of the Barcelona Centre for International Affairs (CIDOB) $<$ https:// www.cidob.org/en/articulos/anuario_internacional_cidob/2019/sanctuary_cities_a_global_perspective> accessed 18 November 2020.

34 See the remarks by Penny Abeywardena, 'Cities and Other Sub-National Entities: What Promise Do They Hold for International Law (Closing Plenary)' (2020) 114 Proceedings of the American Society of International Law 362, at 363.

${ }_{35}$ Monica Salomon, 'Paradiplomacy in the Developing World' in Mark Amen et al. (eds), Cities and Global Governance - New Sites for International Relations (Ashgate 2011) 45, 58.

36 See also the contribution of Mauricio Rodas in this volume.

37 See the perceptive analysis of the 'Amsterdam Human Rights Agenda' in Lisa Roodenburg, Anticipating Friction - The Role of Human Rights in Urban Debates on Migration and Diversity: The Case of Amsterdam, Hong Kong and Buenos Aires (PhD thesis, UvA 2020).

38 Mayo Moran, 'Shifting Boundaries: The Authority of International Law' in Janne E. Nijman and André Nollkaemper (eds), New Perspectives on the Divide between National and International Law (Oxford University Press 2007) 163-190; see also on persuasive authority Karen Knop, 'Here and There: International Law in Domestic Courts' (2000) 32 New York University Journal of International Law and Politics 501.

39 Janne E. Nijman, 'The Renaissance of the City as a Global Actor - The Role of Foreign Policy and International Law Practices in the Construction of Cities as Global Actors' in Andreas Fahrmeier et al. (eds), The Transformation of Foreign Policy: Drawing and Managing Boundaries from Antiquity to the Present (Oxford University Press 2016). 
by individual cities, others by city networks while still others see cooperation between cities, their networks and international organisations. This cooperation is very often in the interests of the latter as they seek a closing of a perceived legitimacy gap..$^{40}$ In addition, it is in particular in the development context that some IOs conceive of direct interaction with cities and their governments as more efficient than the traditional channels of cooperation with central state governments. Increasingly, too, states engage directly with city networks, lending further evidence to the view that the reality of global city action is here to stay. ${ }^{41}$ The accreditation of local authorities at the Habitat III Conference is a case in point. Previously, UN-Habitat was a state-steered programme, but today local governments are allowed to participate in this setting, ${ }^{42}$ even if broader plans for a reform of UN-Habitat that would have led to an even stronger form of representation of cities at the UN level have met with considerable opposition from some states. ${ }^{43}$

\section{FROM NEGLECT TO CAREFUL EMBRACE: A BRIEF OVERVIEW OF THE STATE OF THE ART ON CITIES AND INTERNATIONAL LAW}

The emerging global role of cities has also slowly begun to make its mark on the scholarship of international law. For most of the twentieth- as well as early-twenty-first-century international law scholarship, it is apt to speak of an 'invisibility' of cities. ${ }^{44}$ If they appeared at all, they only made cursory appearances and then as organs of the state. Accordingly, it is clear that cities and local governments can trigger state responsibility for the violation of international obligations of their state under the customary international law rule on attribution of conduct, which is codified in Article 4 of the ILC Articles on State Responsibility. ${ }^{45}$ In law-making processes, cities and their practice may play a role in certain instances, either in the form of subsequent practice under Article 31(3)(c) of the Vienna Convention on the Law of Treaties ${ }^{46}$

40 ibid 219.

${ }^{41}$ For a recent analysis of the engagement with cities at UN level see Anna Kosovac and Michele Acuto, 'Acknowledging Urbanization: A Survey of the Role of Cities in UN Frameworks' (2020) 11 Global Policy 293.

42 On the challenges of direct city representation see the remarks by Robert Lewis-Lettington, 'Cities and Other Sub-National Entities: What Promise Do They Hold for International Law (Closing Plenary)' (2020) 114 Proceedings of the American Society of International Law 366.

${ }_{43}$ See further Michele Acuto, 'Cities are Gaining Power in Global Politics - Can the UN Keep up?' (The Conversation 14 September 2017) $<\mathrm{https}$ ://theconversation.com/cities-are-gaining-power-in-global -politics-can-the-un-keep-up-83668> accessed 13 November 2020.

44 See the contribution of Mirko Sossai in this volume; a related claim has been made for the field of (comparative) constitutional studies, see Ran Hirschl, City, State - Constitutionalism and the Megacity (OUP 2020); see also now the contributions in Ernst Hirsch Ballin et al (eds), 'The City in Constitutional Law' (2021) 2 European Yearbook of Constitutional Law.

45 Articles on the Responsibility of States for Internationally Wrongful Acts, reprinted in the annex to UN Doc. A/RES/56/83 (2001); see further James Crawford and Murielle Mauguin, 'Les collectivités territoriales non-étatiques et le droit international de la responsabilité' in Société française pour le droit international (ed.), Les collectivités territoriales non-étatiques dans le système juridique international (Pedone 2002) 157.

${ }_{46}$ Compare ILC, Draft conclusions on subsequent agreements and subsequent practice in relation to the interpretation of international agreements, with commentaries, reprinted in UN Doc. A/73/10, Conclusion 5, para. 7. 
or for the generation of state practice as an element of customary international law. ${ }^{47}$ Yet, this was never really singled out as city action but rather as state practice.

The international activities of cities as such were not taken into consideration for the most time, however. This began to change with a first wave of publications around the year 2006 . Yishai Blank and Gerry Frug together with David Barron published three articles detailing how cities would begin to engage with international law, how they would form city networks and how this in turn also affected local government (law) ${ }^{48}$ Taken together, these three articles articulated a number of questions that still animate the scholarship on cities in international law today. They were concerned with the emancipation of cities from their traditional role as mere administrative sub-units. They recognised how city networks were seeking to establish a forum for cities at the international level, which liberated them from the need to play only the role of observers in the world of the formal IOs set up by states. These articles also pointed to how local policy space became internationalised, which was both a constraint but also an opening for influencing policy in ways that were previously not available to them. ${ }^{49}$

Taken together, the three articles should have been a wake-up call for both local government lawyers and scholars from the field of international law. However, not much happened at first. Apart from occasional articles, the call fell on largely deaf ears. This changed around 2010 when a second wave of scholarship took off. ${ }^{50}$ Greatly encouraged by the writings of Blank, Frug and Barron - that were pretty much everything that was around - scholars like the editors of this volume started to move into the field. This brought different impulses to the emerging debate - in part an interest in the historical and theoretical questions posed by the emergence of cities as international actors and a curiosity for the effect that this development had on the traditional doctrinal categories of public international law. In parallel to this

47 Sir Michael Wood, Second Report on the Identification of Customary International Law, UN Doc. A/CN.4/672 (2014), para. 34 with footnote 78; for a different view see, however, ILA, London Conference 2000, Committee on the Formation of Customary (General) International Law, Final Report of the Committee, Statement of Principles Applicable to the Formation of General Customary International Law, reprinted in: ILA (ed.), Report of the Conference, vol. 69 (2000), Vol. II, 712, at 727-728.

48 See Frug and Barron (n 6); Blank (n 6).

49 Unaware of these three articles, one of us discussed the initiative of the Mayor of Seattle to implement the Kyoto Protocol at the local level, and the US Mayors Climate Protection Agreement while the US Federal Government failed to ratify the Kyoto Protocol, in the context of 'the process of de-formalization' as an 'illuminating example of the transcendence of the divide [between national and international law] bypassing the issue of bindingness and simply adopting the values contained in (non-binding) international law as normative and directive'; see Janne E. Nijman and André Nollkaemper, 'Beyond the Divide' in Janne E. Nijman and André Nollkaemper (eds), New Perspectives on the Divide between National and International Law (Oxford University Press 2007) 351-352.

50 Ileana Porras, 'The City and International Law: In Pursuit of Sustainable Development' (2009) 36 Fordham Urban Law Journal 537; Janne E. Nijman, 'The Future of the City and the International Law of the Future' in Sam Muller et al. (eds), The Law of the Future and the Future of Law (Topahl 2011) 213; Helmut Philipp Aust, 'Auf dem Weg zu einem Recht der globalen Stadt? "C40" und der "Konvent der Bürgermeister” im globalen Klimaschutzregime’ (2013) 73 Zeitschrift für ausländisches öffentliches Recht und Völkerrecht 673; Helena Lindemann, Kommunale Governance. Die Stadt als Konzept im Völkerrecht (Mohr Siebeck 2014); Tatjana Chionos and Sue Gonzalez Hauck, 'Städtenetzwerke zur Krisenbewältigung - Neue Völkerrechtakteure als Herausforderung für die konstitutionelle Idee' in Jonathan Bauerschmidt et al. (eds), Konstitutionalisierung in Zeiten globaler Krisen (Nomos 2015) 191; Helmut Philipp Aust, 'Shining Cities on the Hill? The Global City, Climate Change, and International Law’ (2015) 26 European Journal of International Law 255; Nijman (n 39) 209. 
development, critical scholars of international law and those identifying themselves with the so-called school of 'Third World Approaches to International Law' (TWAIL) also began to be increasingly concerned with the everyday effects of international law. Inspired also by critical work done earlier by David Harvey and Henri Lefebvre, the study of international law moved into examining how international law played out in discreet local contexts. Luis Eslava's work brought a distinct sensibility for an anthropological approach to the field. ${ }^{51}$ And Balakrishnan Rajagopal, one of the leading voices of the TWAIL movement, developed a new and original line of work on the 'right to the city', ${ }^{52}$ quite possibly also fuelled by his affiliation with the Department of Urban Planning at MIT. With the turn to empire in international legal history, the development of international law is now studied through the prism of urban locations around the world. ${ }^{53}$

This second wave of scholarship in international law also coincided with an increasing amount of publications in the field of international relations where scholars like Sofie Bouteligier, Michele Acuto and Simon Curtis published important monographs, edited volumes and articles on the growing international role of cities. ${ }^{54}$ Although the work of sociologists like Saskia Sassen and urban geographers was very well known among those working on cities from an international law perspective, this parallel emergence of the topic in the field of IR arguably helped to make international lawyers in general more aware of the development. Political science and in particular the sub-field of IR is to many working in the field of international law the natural go-to place when they consider interdisciplinary cooperation and when they seek inspiration for new topics. The language of the two disciplines is fairly close to each other and there is an established pathway for interdisciplinary cooperation. Some of these IR scholars, like Michele Acuto, were also lawyers by training - which might have inadvertently helped them to write in a style and approach that international lawyers found appealing and could relate to.

The last ten years have seen, finally, the unfolding of a new and dynamic research field. It is noticeable that two subject areas are especially well covered now. The field of climate change governance is probably the most prominent example for a field in which cities have by now become accepted as important actors, the question of their subjectivity notwithstanding..$^{55}$ This state of play is a consequence of the high profile that networks like $\mathrm{C} 40$ have acquired in

51 Luis Eslava, Local Space, Global Life - The Everyday Operation of International Law and Development (Cambridge University Press 2015).

52 Balakrishnan Rajagopal, International Law from Below - Development, Social Movements and Third World Resistance (Cambridge University Press 2003); for an exploration of his concept of the 'right to the city' see this video lecture: 'The Right to the City as a Human Right', 24 October 2016 $<$ https://urbandemos.nyu.edu/2016/10/24/video-the-right-to-the-city-as-human-right/> accessed 22 October 2020.

53 See for example Luigi Nuzzo, 'The Birth of an Imperial Location: Comparative Perspectives on Western Colonialism in China' (2018) 31 (3) Leiden Journal of International Law 569; see for example Michael Goebel, Anti-Imperial Metropolis: Interwar Paris and the Seeds of Third World Nationalism (Cambridge University Press 2015).

54 See the references in (n 3) and Simon Curtis, Global Cities and Global Order (Oxford University Press 2016); Simon Curtis, 'Cities and Global Governance: State Failure or a New Global Order?' (2016) 44 Millenium 455; Ian Klaus and Michele Acuto, 'Introduction' (2018) 12 New Global Studies 1; Simon Curtis, 'Global Cities and the Ends of Globalism' (2018) 12 New Global Studies 75.

55 Jolene Lin, Governing Climate Change: Global Cities and Transnational Lawmaking (Cambridge University Press 2018); Helmut Philipp Aust, 'The Shifting Role of Cities in the Global Climate 
the climate change regime. It is also noticeable how the climate change regime has gradually moved towards a cautious recognition of the role that cities have to play in this regard. This dual development - one bottom-up, epitomised through the practice of the city networks, and the other top-down, through decisions of the Conferences of the Parties of the UNFCCC and through other avenues of IOs - has given international lawyers plenty of material to work with and think through the implications of the emergence of the city on the international level.

A second field in which there is now a wealth of publications concerns the relationship between cities and the protection of human rights. ${ }^{56}$ In part, this overlaps with debates about a possible 'right to the city' although the idea of protecting human rights through the practice of local governments and the call for a (revolutionary) re-appropriation of urban space in the sense of Henri Lefebvre may be two quite distinct matters. In any case, important work has now been contributed, for instance by Karen Knop and Martha Davis, on the protection of human rights at the local level and how this may have contributed to what Sally Merry Engle has called in a different context the 'vernacularization' of human rights..$^{57}$ The most famous (and most-quoted) example in this regard refers to the 'enactment' as a municipal ordinance of the Convention on the Elimination of All Forms of Discrimination Against Women (CEDAW) by San Francisco, a step that was emulated with respect to this convention and other international instruments not ratified by the United States by a considerable number of other cities and counties in the United States. ${ }^{58}$ In a team with sociologists interested in the protection of human rights at the local level, Barbara Oomen has published widely on human rights cities and the pursuit of global justice through local channels. ${ }^{59}$ Most recently, this has also led her and others to study intensely the role that local governments and cities can play in the context of the increasingly debated migratory constellation in which we find ourselves. ${ }^{60}$ It is noticeable that this debate is also intimately connected to current debates about US politics where so-called 'sanctuary cities' increasingly question the authority of the federal government, in particular with respect to the treatment of undocumented migrants. But as it is also documented throughout many different chapters in this book, this question is far from being specific to the US. Migration, in particular, is a reality across the globe and many cities find themselves

Change Regime: From Paris to Pittsburgh and Back?' (2019) 28 Review of European, Comparative and International Environmental Law 57.

56 Barbara Oomen, Martha F. Davis and Michele Grigolo (eds), Global Urban Justice - The Rise of Human Rights Cities (Cambridge University Press 2016); Michele Grigolo, The Human Rights City New York, San Francisco, Barcelona (Routledge 2019).

57 Karen Knop, 'International Law and the Disaggregated Democratic State: Two Case Studies on Women's Human Rights and the United States' (2012) 6 Rapoport Center Human Rights Working Paper Series; Martha F. Davis, 'Design Challenges for Human Rights Cities' (2017) 49 Columbia Human Rights Law Review 27.

58 Judith Resnik, 'Comparative (In)equalities: CEDAW, the Jurisdiction of Gender, and the Heterogeneity of Transnational Law Production' (2012) 10 International Journal of Constitutional Law 531; Heidi Nichols Haddad, 'When Global Becomes Municipal: US Cities Localizing Unratified International Human Rights Law’ (2020) 31 European Journal of International Law 1379.

59 Barbara Oomen and Moritz Baumgärtel, 'Frontier Cities: The Rise of Local Authorities as an Opportunity for International Human Rights Law' (2018) 29 European Journal of International Law 607; Elif Durmuş, ‘A Typology of Local Governments' Engagement with Human Rights: Legal Pluralist Contributions to International Law and Human Rights' (2020) 38 Netherlands Quarterly of Human Rights 30.

60 Barbara Oomen, 'Decoupling and Teaming up: The Rise and Proliferation of Transnational Municipal Networks in the Field of Migration' (2020) 54 International Migration Review 913. 
confronted with the need to deliver solutions to the real world problems and challenges of both migrants and the communities in which they arrive and seek to make a living. It is also not unusual to see a polarisation between national governments and their most important cities, as most recently the 'Pact of Free Cities' between Budapest, Bratislava, Prague and Warsaw testifies. ${ }^{61}$ Even in the security context, local governments across the world refer to global norms and practices, be it with respect to macro-level questions like nuclear disarmament or to the more immediate questions of preventing terrorism and other forms of violence in their cities. ${ }^{62}$ In all these contexts, international norms and city-to-city connections across states play a significant role.

\section{FROM MAPPING EXERCISES TO THE MASCHINENRAUM OF THE LAW: RESEARCH PERSPECTIVES AND THE APPROACH(ES) OF THIS HANDBOOK}

It is on the basis of this already very rich scholarship that the present Research Handbook makes a contribution to the further development of the field. This book has been designed in reaction to various avenues for future research that we have identified on the basis of our previous work in the field. In particular, we see the need for more work in three different ways: First, it is still necessary to broaden the empirical basis of our understanding of what cities do when they 'go global'. The ambition of the Handbook is not merely descriptive in this regard. Rather, the contributions seek to shed light on how different practice areas of international law are now also inhabited by cities and their activities. It is by now well accepted that some policy fields and subject areas are shaped by the activities of cities. This holds true most prominently for climate change governance, human rights and migration. While these fields remain important reference points for the debate - and hence are covered prominently in this volume ${ }^{63}$ - the contributions to this volume show that cities are now active in many other fields, be it environmental governance in a more general sense, ${ }^{64}$ counterterrorism, ${ }^{65}$ development cooperation, ${ }^{66}$ health governance, ${ }^{67}$ or economic cooperation. ${ }^{68}$ The city has also made its mark on the shaping of transnational regimes of law, like in the case of the Olympic games. ${ }^{69}$ That all this is not happening as mere academic pipedreams is illustrated by a dedicated chapter focusing on the perspective of the former Mayor of Quito, Mauricio Rodas, who was deeply involved in both international activities and the organisation of the Habitat III Conference in $2016 .{ }^{70}$ Collectively, the chapters on practice areas show that international law is appropriated

See city report on the Pact by Lena Riemer, documented at the ILA SG website (n 7).

62 See further Helmut Philipp Aust, Das Recht der globalen Stadt - Grenzüberschreitende Dimensionen kommunaler Selbstverwaltung (Mohr Siebeck 2017) 325-362.

63 See the contributions in this volume Chapter 15 on climate change by Anél du Plessis, Chapter 18

on human rights by Martha F. Davis and Chapter 19 on migration by Barbara Oomen.

64 See Chapter 16 by Jolene Lin in this volume.

65 See Chapter 17 by Alejandro Rodiles in this volume.

66 See Chapter 20 by Michael Riegner in this volume.

${ }^{67}$ See Chapter 21 by Christian Iaione and Elena de Nictolis in this volume.

68 See Chapter 22 by Jorge E. Viñuales and Lucy Lu Reimers in this volume.

69 See Chapter 23 by Antoine Duval in this volume.

70 See Chapter 24 by Mauricio Rodas in this volume. 
by cities. They accept it to be normatively relevant, if not binding, and as such seek influence increasingly in its creation. Regardless of still-prevailing views about the formal definition of international law, its subjects and sources, the Handbook testifies to the expanding horizons of international law. It also, however, testifies to the ambiguities and politics that come with the interpretation and application of international law in the urban context.

Second, the scholarship on cities and international law needs to descend down into the Maschinenraum of the law in order to better understand how the foundational categories of international law - subjectivity, ${ }^{71}$ sources doctrine, ${ }^{72}$ responsibility ${ }^{73}$ and the like - condition what cities can do within international law. In turn, we are interested in how these categories may be affected by the practice of cities. Can we witness, for instance, that processes of international dispute settlement become affected by the growing acceptance of cities as international actors? ${ }^{74}$ What role do international organisations, as the second-most central category of actors in the international legal system, play for the growing role of cities on the international level $?^{75}$ And could one even say that sovereignty, arguably the foundational concept of the international legal system as such, is undergoing yet another fundamental change? ${ }^{76}$

Third, practice and doctrine are not all that (should) exist(s) in the pluriverse of international legal scholarship. Accordingly, this Research Handbook aspires to provide for various forms of contextualisation. We have thought it apt to bring the international legal discourse into contact with other disciplines. Accordingly, a number of contributions engage with the legal dimension of the emergence of cities as global actors from the perspective of their respective disciplinary backgrounds. For a long time, the international legal discourse has primarily 'learned' from the pioneering work in other fields and it is now tempting to see whether these other disciplines can also benefit from hearing back what international lawyers have in the meantime accomplished. Accordingly, our collection is also enriched with contributions from the perspective of international relations scholarship ${ }^{77}$ and political theory. ${ }^{78}$ It also probes into the sociological dimension of the growing international role of cities. ${ }^{79} \mathrm{We}$ also think, however, that theoretical reflection on the role of cities is not something external to an international law approach to the topic. Rather, international law allows for its own approaches towards theorising the role of cities on the international level and this volume aspires to do justice to a whole variety of existing theoretical approaches in the field, ranging from an exploration into the democratic argument for a greater role of cities in international law ${ }^{80}$ to an exploration of the particular urban (in-)sensibilities of international law ${ }^{81}$ to the concept of inter-legality and what it can offer for the study of cities as global actors. ${ }^{82}$ Some contributions also focus specifically on the translation of insights from IR scholarship into the field

\footnotetext{
See Chapter 9 by Yishai Blank in this volume.

See Chapter 10 by Yukiko Takashiba in this volume.

See Chapter 11 by Katja Creutz in this volume.

See Chapter 12 by Moritz Baumgärtel in this volume.

See Chapter 13 by Jacob Katz Cogan in this volume.

See Chapter 14 by Anouche Beaudouin in this volume.

See Chapter 25 by Simon Curtis in this volume.

See Chapter 26 by Nir Barak and Avner de Shalit in this volume.

See Chapter 34 by Daniel Litwin in this volume.

See Chapter 27 by Samantha Besson and José Luis Martí in this volume.

See Chapter 35 by Karen Knop in this volume.

82 See Chapter 33 by Jan Klabbers in this volume.
} 
of international law. ${ }^{83}$ The Handbook also connects the topic of our analysis with scholarship on earth system law ${ }^{84}$ and global administrative law, ${ }^{85}$ as well as local government law and its constitutional law foundations more generally. ${ }^{86}$ The volume also bears out how the notions of urban governance and local government law change by virtue of both developing international normative expectations and feedback loops from the local level to the international. ${ }^{87}$

We have in particular considered it to be important to include a number of reflections on the historical dimension of our topic in the volume. All too often legal scholarship is enchanted by a new phenomenon that is seemingly discovered - only to learn that things may not be so ground-breaking after all. Some historical analogies are very present in the city discourse, like references to the towns and cities on the Chinese Silk Road(s) ${ }^{88}$ the Hanseatic League ${ }^{89}$ and Italian city republics. ${ }^{90}$ By including chapters on these historical aspects, we are not arguing that easy and convenient lessons can be learned and that, for instance, we are moving into a new era akin to the 'Middle Ages', where all cities are now Hanse cities, as was proclaimed emphatically some time ago by Benjamin Barber. ${ }^{11}$ Still, earlier experiences of relations among cities within shared legal realms help us see more clearly the contingencies of the current international legal order. They may provoke our imagination of what can be possible, maybe not in the next ten or twenty years but in a timeframe beyond that. Also, the historical perspective helps us see how important economic situations and developments are for cities and their networks. This message is drawn out further by historical explorations of cities and imperial ordering ${ }^{92}$ and the role of decolonisation ${ }^{93}$ as well as reflections on the political economies behind the ever-evolving relationship between states and cities across time. ${ }^{94} \mathrm{Cities}$ may have been invisible in international law for quite some time, but upon a closer look one may discern that their presence could always be identified, if at times in indirect ways. ${ }^{95}$

This Research Handbook is committed to pluralism with respect to the approaches it brings together. As the contributing authors do not hail from one particular school or geographical background we have considered it unappealing (to attempt) to impose too much conceptual unity on our authors. Accordingly, different contributions to this volume will have different understandings of what notions and key concepts like international law, global law, urban law or transnational law mean. We have also been open for different types of contributions. Whereas the mission of our Research Handbook is primarily analytical, we acknowledge that it will not be possible to write about an emerging topic like ours without any normative bend. The authors of the respective contributions have been asked to be transparent about their approach and a possible normative stance they might have. We consider transparency to be of

\footnotetext{
See Chapter 29 by Sheila Foster and Christie Swiney in this volume.

See Chapter 28 by Louis J. Kotzé in this volume.

See Chapter 32 by Edouard Fromageau in this volume.

See Chapter 30 by Geneviève Cartier in this volume.

See Chapter 31 by Carlo M. Colombo and Martijn L.P. Groenleer in this volume.

See Chapter 2 by Valerie Hansen in this volume.

See Chapter 3 by Tobias Boestad in this volume.

See Chapter 4 by Susanne Lepsius in this volume.

91 Benjamin R Barber, If Mayors Ruled the World: Dysfunctional Nations, Rising Cities (Yale

92 See Chapter 5 by Luigi Nuzzo in this volume.

93 See Chapter 7 by Luis Eslava and George Hill in this volume.

94 See Chapter 8 by Boris Vormann in this volume.

95 See Chapter 6 by Mirko Sossai in this volume.
} University Press 2013). 
primordial importance here. We have personally observed through a process of self-analysis that we too as editors were for some time enchanted by our subject. International lawyers are often as idealistic and enthusiastic about their work as they are disenchanted by the state system and the manifold failures and shortcomings it produces. The emergence of a new type of actor can seem liberating, especially if it is primarily seen to play a role in confronting urgent global challenges like climate change, a pandemic crisis, the uncertain future of multilateralism or the unsettling and undermining of the protection of human rights. Accordingly, many aspects of the practice of cities have invited projections of liberal and progressive intentions onto what cities have been up to. These projections may be warranted in many cases and we admit on our part a continuing fascination for the emancipatory potential that cities may bring to the international level. But not all is golden here. Cities may be employing at times questionable arguments of democratic legitimacy. City networks may be prone to capture by the interests of powerful stakeholders from the private sector. The focus on cities may blur the impact of all the buzz around 'the urban age' on the Hinterland of the current and shiny metropolises, overlooking that however green and sustainable a well-developed global city may appear to be, it is still caught up in infrastructure and production networks without which it could not function. And too much euphoria about cities replacing the state are esoteric in the first place. By arguing for an 'urban turn' in international legal scholarship, we do not wish to diminish in any meaningful sense the central role that the state plays in the current international legal order, nor do we envisage it being replaced in the foreseeable future. Accordingly, we have invited our authors not only to be transparent about their normative project (if there is one), but also to embrace the many ambivalences that contemporary practices of cities may portray.

Despite our own embrace of a pragmatic, flexible and pluralistic approach to fundamental concepts, a number of clarifications on the ambit and approach of the volume can be given. We have deliberately decided that this is a book on cities and international law, understood in the sense of 'public international law'. This brings a certain conceptual baggage with it that some may find to be a straitjacket rather than springboard. It would certainly be easier to write about the global practices of cities merely from the viewpoint of a loose concept of global legal pluralism or transnational law in which everything can be easily integrated. But the focus on international law is purposive. We consider the tension between the practice of what cities do today and the traditional categories of international law to be particularly fruitful. It forces us to take another look and can also enable us to open up our thinking about international law, identifying parts where it may be lagging behind real world developments and may not provide us with adequate conceptual tools to address pressing current issues. In all of this a critical outlook on international law and its use remains called for since there is no reason to assume that the city's engagement with international law other than the state's is inherently just or good. Our focus is hence both an attempt to understand what cities do from a specific international law perspective and an invitation to think afresh about the possible new horizons that this development brings for international law.

In a nutshell, this Handbook lays the ground for the further scholarly research and dialogue on cities and international law. It makes the case for a historically and theoretically informed approach to the question under analysis. We believe that the practices of cities in this regard are as important as an understanding of how key concepts of international law inform and limit these practices and may in turn be transformed by these practices themselves. The many different disciplinary and theoretical angles in this volume testify that this is a dynamic research field whose importance has just begun to be understood. 
At the end of the chapters in this volume, authors provide us with pointers for further research. These are intended to help researchers in the field identify emerging trends and possible future topics. It is self-understood that these pointers for further research are shaped by the subjective position of our group of authors. We are confident, however, that collectively this volume will be a fair assessment of where we stand with respect to the role of cities in international law. We look forward to the continuing conversation. 